\title{
Education Policy on The Prohibition of Smoking In A Campus Environment
}

\author{
Dinil Abrar Sulthani, Kunaenih \\ Universitas Islam Jakarta, Jl. Balai Rakyat, Utan Kayu No.64, Jakarta Timur, Jakarta 13120 \\ Correspondence Email: dinil_umsb@yahoo.com
}

\begin{abstract}
The existence of a smoking prohibition policy in the campus environment is the best effort in maintaining a good and conducive learning environment. The purpose of this study was to find out the response and a model for the prohibition of smoking. The research location at the Islamic University of Jakarta (UID), using the research method used by Research and Development $(\mathrm{RnD})$. This development research will involve 18 respondents consisting of 6 lecturers/staff and 12 students with random respondents. The findings showed that most of the respondents' information agreed with the prohibition of smoking in the campus environment. Respondents also realized that smoking activities had to be stopped both from self-awareness and from the regulations imposed by the Head of UID Institution. Conclusions that can be cited; 1) The response to the establishment of a smoking ban policy in the UID environment is still low. Does not reach more than more than $70 \%$ of the respondents' answers. 2) The model for smoking prohibition policies that can be taken by university leaders is to hold various activities that support the go green program. As; stop smoking campaigns, hold seminars or workshops, and add symbols that prohibit smoking in the UID environment.
\end{abstract}

Keywords:

Policy; Smoking Prohibition; Response and Model

\begin{abstract}
Abstrak
Adanya kebijakan larangan merokok di lingkungan kampus adalah upaya terbaik dalam menjaga suasana lingkungan belajar yang asri dan kondusif. Tujuan penelitian ini untuk mengetahui respon dan menemukan model tentang larangan merokok. Mengambil lokasi penelitian di Universitas Islam Jakarta (UID), dengan menggunakan metode penelitian yang digunakan Research and Development (RnD). Penelitian pengembangkan ini akan melibatkan 18 responden yang terdiri dari 6 dosen/karyawan dan 12 mahasiswa UID dengan pengambilan responden yang acak. Hasil temuan didapatkan bahwa sebagian besar informasi responden menyatakan setuju dengan adanya larangan merokok di lingkungan kampus. Responden juga menyadari bahwa kegiatan merokok harus dihentikan baik dari kesadaran diri sendiri, maupun dari regulasi yang diberlakukan oleh Pimpinan Lembaga UID. Kesimpulan yang dapat kutip; 1)Respon terhadap dibentuknya Kebijakan pelarangan merokok di lingkungan UID masih tergolong rendah. Tidak mencapai melebihi di atas 70\% atas jawaban para responden. 2)Model kebijakan larangan merokok yang bisa ditempuh oleh pimpinan universitas adalah dengan mengadakan berbagai kegiatan yang mendukung program go green. Seperti; kampanye stop smoking, mengadakan seminar atau workshop, dan menambahkan simbol-simbol larangan merokok di lingkungan UID.
\end{abstract}

\section{Kata Kunci:}

Kebijakan; Larangan Merokok; Respon dan Model

\section{Introduction}

The prohibition of smoking on campus should be in agreement among the academic community. The smoking prohibition is aimed at promising a measure of energy, free of cigarette smoke pollution, and maintaining the health of the body and the local environment. However, there were still some students and lecturers who smoked on campus. This matter illustrates that there needs to be an emphasis from policy makers to provide affirmation so that every campus community keeps the environment good and conducive. 
Based on observations about the environmental conditions of UID that smoking actors are still found and several descriptions of the dangers of smoking, this research is trying to produce an idea (model) that can be recommended to the UID leadership to declare a smoking prohibition policy for peace, beauty, and preservation of a green campus atmosphere smoke free. This development research will involve 18 respondents consisting of 6 lecturers or employees and 12 students of the UID with random respondents. There are two kinds of test instruments used. Scale of measurements on the instrument using the Guttman scale. This scale has an explicit assessment of yes or no. In this study, "yes" is expressed as a score of 2 and "no" is expressed as a score of 1 (Sugioyono, 2008).

Previous researchers Prabandari, et al. (2009) conducted a similar study regarding the Application of a SmokingFree Campus Policy at the UGM Faculty of Medicine. In this study, the percentage of nonsmokers increased by $19.1 \%, 6 \%$ quitting after implementing a smoking prohibition, and $7 \%$ reducing the number of cigarettes they smoked. This matter also needs to be applied in the UID environment in order to reduce smoking in the academic community. Basically, every smoker is an object of research that must be guided and directed to leave the smoking habit. For this reason, it is important to carry out this research so that it can help direct the direction that is good for smokers. This research was conducted in the UID environment because it remembers data from mapping and observations.

Awareness about the dangers of smoking for the campus community needs to be increased, so that the number of cigarette perpetrators can be reduced to a decline. Consciously or not, smoking will have a negative impact on all parties. The negative impact can be seen from several aspects, including; First, Smoking damages the health of the body. It cannot be denied that in the contents of cigarettes there is a mixture of substances that can have a harmful impact on the body, such as opium, damage to the lungs, decaying teeth and gums, difficulty breathing, body odor, and many more. The same thing was expressed by Abadi in Marsito, et al (2009) that cigarette smoke is very dangerous which contains 4000 chemical toxins, and 43 of them are carcinogenic which can lead to cancer.

Second, Smoking disrupts the economic system. In mathematical calculations, if a smoker spends one to three packs a day then it is worth the price to provide one day of living to family members. Smokers freely "burn" money in order to complete the taste of their addiction to cigarettes. Meanwhile, if the money to buy cigarettes was diverted for household needs, it would be better. Lecturers and students who smoke can be indicated that they do not see thoroughly the use of money according to their most priority needs.

And Third, Smoking damages future generations. Teens who have contracted the addiction to smoke have opened another door of evil for him. The door to evil is a continuation of the addiction to the highest level, namely using Narcotics. This happens because the curiosity of teenagers and young people to try new things that are more challenging, but the choice of method is wrong. "The development of these children who are looking for self-identity and always want to try new things in their environment (Salmawati, et al, 2016)". So that he was trapped in a valley which made him worse off. In other words, smoking is the key to opening the gates of Narcotics.

The purpose of this research is that lecturers and students who smoke in the UID environment can be aware of the 
dangers of smoking, specifically knowing the right places and situations for smoking. The campus is not the right place to smoke, if you want to smoke then you must be aware of looking for other places, for example outside the campus. The establishment of a smoking prohibition policy in the UID environment. Which provides a representative picture of the campus that supports the GoGreen movement. Because, behind a healthy body there is a healthy soul, behind a healthy campus there are campus people who obey the regulations.

\section{Smoking Prohibition Policy}

The prohibition of smoking needs to get special attention in educational institutions, especially the UID environment. Health Law No. 36 of 2009 article 115 states that the University is one of the seven areas declared as smokingfree areas, so that every campus that is located in the territory of Indonesia should apply its environment as a smokefree area.

This matter is based on; First, The condition of Indonesia which occupies the third position after China and India, with data on Indonesian teenage boys as much as $24.1 \%$ and $4 \%$ female adolescents, while male adult smokers are $63 \%$ and $4.5 \%$ are women. adults (Salmawati, 2016). And according to WHO data, Indonesia is ranked third with the largest number of smokers in the world, after China and India (2). More than 40.3 million Indonesian children aged $\mathrm{O}-14$ years become passive smokers by inhaling cigarette smoke in their neighborhood (3). In 2014, Indonesia was the only country in the Asia Pacific that had not ratified the Framework Convention on Tobacco Control (FCTC). Indonesia already has regulations that support the control of tobacco consumption and the dangers of consuming cigarettes, Indonesia has also implemented control measures, including no-smoking areas and a power strategy (TCSC in Popa, 2016).

Second, Some students and lecturers are still found smoking freely, this provides learning (exemplary) indirectly to others who are feared trying to imitate. There is a need for socialization and education efforts for the community, especially campus people who are smokers. Education is important because smokers are reminded to be aware of the dangers of smoking for their health. This awareness is born from complete knowledge and understanding of the serious effects of smoking. This matter is in line with Notoadmojo's statement in Salmawati (2016) that people who have knowledge about cigarettes tend not to smoke, on the other hand those who do not understand about smoking tend to smoke behavior.

Furthermore, knowledge always goes hand in hand with efforts to provide complete information about the dangers of smoking. Apart from being on campus, smokers need to be exemplary from many parties, if at home he sees family members smoking then he will tend to try too (Priyatin, 2009). The same analogy also applies on campus, students who have not previously smoked because they saw their friends smoking or the lecturers were smoking, so the tendency to follow is possible.

Therefore, it is necessary to compile material content that can support smoking prohibition policies, including by:

a. The "Stop Smoking" campaign (Umar, et al, 2011). This campaign is intended for campus people who are still and don't smoke.

b. Create anti-smoking or smoking symbols

c. Form a team of observers who monitor smoking prohibition policies 
d. Student volunteers who campaign for non-smoking are guerrilla, and

e. Regulations from university leaders regarding smoking prohibition within UID, by letter, the legal umbrella that applies to the entire academic community.

The smoking prohibition policy should be easily implemented for all campus communities. By realizing together, there is a need for agreement that the campus is a smoke-free or nonsmoking area. "The implementation of smoke-free areas is one of the efforts to protect those who do not smoke but are exposed to secondhand smoke or secondhand smoke (Prabandari, 2009).

The material content that has been discussed previously is strived for gradually, but the researchers see point 5, namely the regulation from the campus leadership, is the first step that must be taken. The summary of these regulations will later be strengthened through the results of this research report by synchronizing the data and information from each respondent who provides their arguments. The theoretical concepts that have been formulated in chapter 2 will be combined with the results of the research so that policies issued are based on reliable research.

\section{Research Methods}

The research method used in this research is the research and development method Research and Development $(\mathrm{RnD})$. RnD is used because a model needs to be developed first and in this method there is a test. The $\mathrm{RnD}$ design used in the development was the S. Thyagarajan 4-D development model. The 4-D development model is a learning development model. The 4-D development model consists of 4 main stages, namely: (1) Define or Limitation, (2) Design or Design, (3) Develop or Development and Disseminate
Deployment, or adapt (Trianto, 2007). This development research will involve 18 respondents consisting of 6 lecturers/staff and 12 UID students with random respondents.

In the Policy Model for the Prohibition of Smoking in the UID Environment. Planning activities to be carried out are described as follows;

a. Define Stage (Define)

The purpose of this stage is to define and define the terms of the policy starting with the objective analysis of the material boundaries being developed.

b. Planning Stage (Design)

The purpose of this stage is to prepare learning tools. This stage consists of three steps.

c. Development Stage (Develop) The purpose of this stage is to produce revised learning tools based on input from experts.

d. The stage of spreading (Disseminate)

At this stage, it is the stage of using instruments that have been developed on a broader scale, for example in other campuses or other institutions by other researchers.

\section{Results and Discussion 4.1 Research Findings}

Researchers have conducted interviews with 18 respondents who were randomly selected. Of the 18 respondents, 6 lecturers or staff and 12 students came from different faculties in the Islamic University of Jakarta. From the interviews conducted, the following data were obtained; Of the $78 \%$ respondents who stated smoking, they on average started smoking at the High School level, amounting to 6 respondents, 4 respondents at Junior High School level and 3 respondents at Higher Education. 
Furthermore, it was found that $50 \%$ of respondents said smoking was important, for various reasons or factors such as; eliminating boredom, stress and drowsiness, filling empty time, getting peace, helping tobacco farmers, and a social environment so that it is easy to make friends. Based on these various arguments, it can be concluded that $56 \%$ of respondents stated that smoking supports association in society. Despite this fact, the respondents are aware that smoking is harmful to the health of the body, this is known to be $89 \%$. And $61 \%$ of respondents stated that smoking interferes with household finances and daily finances. And they do it (smoking activity) regardless of the time and the situation. They smoke whenever and wherever they can.

This indicates that the campus can be a smoking place for respondents, this is in line with the findings of the data that $50 \%$ of respondents smoke inside campus buildings. When interviewed, they answered with various arguments such as; "Helping to find inspiration" said the lecturer at the Faculty of Economics at UID. "Because after that there are more lecture hours" said the student of the Islamic Faculty of UID, meaning they did not have time to go outside the building. Another with the expression of one student "imitating other students". And also smoking in the building because it is not prohibited and is not punished by the law, said one student.

In addition, $80 \%$ of respondents stated that cigarette smoke disturbs other non-smokers. They recognize it, but do it anyway. When confirmed why they did it, respondents argued as follows; because smoking is in an open space so it doesn't matter if there are other people, there are also those who argue because they are addicted, or there are no restrictions, some even say they don't care about things around.
When asked about the dangers suffered by others, $94 \%$ of respondents answered that people who do not smoke will be exposed to the dangers of cigarette smoke. However, that understanding is only understanding. Because smokers still do it regardless of friends who are smokers or not. To get around this, the researchers asked respondents whether or not they could smoke outside the campus building, and the result was that $61 \%$ said they could and would like to smoke outside the campus building.

The researchers asked questions that were more substantial in line with the theme of this study, namely about whether or not the smoking prohibition was enforced in the UID campus environment. Based on the questions posed to respondents, $67 \%$ of respondents agreed and $33 \%$ of respondents disagreed. When asked the reason why they disagreed, various answers to the arguments were presented, such as; rigid and not flexible if there is a smoking prohibition, smoking in the campus environment is part of human rights, awareness has not been intended, and no smoking area has been provided.

On the other hand, $72 \%$ of respondents stated that university leaders need to conduct socialization on the prohibition of smoking so that lecturers or employees or students know that the campus is not the right place to smoke. The socialization can be done by providing or putting up symbols prohibiting smoking, this is amini as many as $78 \%$ of respondents. In addition, $61 \%$ of respondents answered that campus leaders also need to organize training/seminars/workshops on the dangers of smoking and they are willing to participate in these events/activities. However, it is also concerning when asked about smoking is the beginning/gateway to starting drug consumption, which agrees with this statement only $17 \%$ of 
respondents. This means that $83 \%$ of respondents do not agree with this statement.

The next data finding is that $67 \%$ of respondents agree with the "Stop Smoking" campaign at the Islamic University of Jakarta. And 44\% of respondents agreed to participate in these activities, $45 \%$ of respondents did not want to participate in these activities, and $11 \%$ of respondents did not answer the questions asked. Therefore, based on the advice of $44 \%$ of respondents, the campus leadership should form a team of observers who take notes and then report to the Chancellor for anyone who smokes in the campus environment.

And of all respondents interviewed as many as $72 \%$ or 13 respondents were willing to quit smoking, $11 \%$ or 2 respondents did not answer, and $17 \%$ or 3 respondents said they were not willing to quit smoking. After the researcher saw and checked, it turned out that 2 respondents who did not answer came from the lecturer, and 3 respondents who stated that they were not willing to stop smoking, namely from the answers of the students. Thus, if it is seen from the average ideal value with a standard of $70 \%$, it is found that the respondent's response to the smoking prohibition policy is classified as low, which does not exceed $70 \%$. This means that the number of smoking prohibitions in the UID environment still needs to be suppressed so that it can reach even more than $70 \%$.

\subsection{Discussion}

Respondents who were interviewed started smoking at the Junior High School level, and mostly at the High School level, and some came from Higher Education. Seeing from these respondents, that at the college level also provides opportunities for those who have not smoked to become smokers. This is one of the reasons that the social environment in college has an impact on the bad habits of friends to hang out with. For this reason, it is necessary for campus leaders to set proper regulations so that all academicians have an awareness that leads to change.

Set regulations appropriately and take into account various things. Because, the phenomena and facts at UID are still found by some students, lecturers/employees who smoke on campus. This regulatory arrangement is expected to provide a new discourse for campus leaders, that to create a conducive atmosphere requires awareness. Awareness that is systematic, comprehensive and comprehensive so that all parties accept these regulations, in order to minimize cigarette consumption in the campus environment.

Usually the reason smokers keep doing their activities is triggered by many factors, so they think that smoking is part of an important and beneficial thing, such as causing sensation and calmness, some are doing nothing for fun, so smoking is an option, some are bored, saturated, stressed then smoking is the answer. It should be understood together that the act of choosing to smoke is caused by opium which forces the brain nerves to ask for opium (dopamine) intake.

The habit of smoking cigarettes can be caused by several influences, including: 1) parental influence, where one of the findings about teenage smokers is that young people come from unhappy households, where parents do not pay much attention to their children and provide physical punishment who are hard, it will be easier to become smokers than young people who come from happy households because smoking is considered capable of eliminating the problems they face. In addition, the habit of parents smoking in the home environment 
can also be a direct example for children to follow their parents' lifestyle. 2) The influence of friends, where the social environment of adolescents will have a huge influence on adolescent attitudes and behavior. 3) Personality factors, where people try to smoke for reasons of curiosity, want to get away from pain, want to get rid of boredom, or want to be seen as a man. 4) The effect of advertising, where advertisements in mass and electronic media present a very clear picture that smokers are a symbol of masculinity and glamor, making adolescents often triggered to follow the behavior in these advertisements (Baer \& Corado in Atkinson, 1999).

The tendency to smoke which is based on reasons that reinforce the importance of smoking, is basically just fake. In other words, these reasons actually trap them into bad habits. Because from a health standpoint, addiction that results in high dopamine needs will reduce the stability of nerve activity. If you want to change all of that, like it or not smokers have to give up their smoking habits with all their might. There is no reason why it is difficult to stop at first, rather than suffering from a long illness later on.

Basically, the respondent also knows and understands the dangers of smoking, but because he is addicted, he will reject all reasons. This is part of self-oppression, in order to satisfy the addictive desire to smoke he is willing to sacrifice his health for the sake of pleasure and serenity due to addiction. The bad consequences of smoking for health have been widely discussed. The results of research in England show that approximately $50 \%$ of smokers who smoke as a teenager will die from smoking-related diseases. Smoking habits have been shown to be associated with approximately 25 types of diseases from various organs of the human body. These diseases include cancer of the mouth, esophagus, pharynx, larynx, lung, pancreas, bladder, and vascular disease. This is also influenced by the habit of drinking alcohol and other factors. (Aditama, 1995).

Smoking-related diseases are diseases that are either directly caused by smoking or are made worse by smoking. Diseases that cause the death of smokers include: 1. Coronary heart disease. Each year approximately 40,000 people in the UK under the age of 65 die from heart attacks and about three quarters of these deaths are due to smoking. Smoking affects the heart in many ways. Smoking can raise blood pressure and speed up the heart rate so that the supply of acid is less than normal for the heart to function properly. This situation can be burdensome to the task of the heart muscle. Smoking also causes the walls of blood vessels to gradually thicken, making it difficult for the heart to pump blood.

2. Coronary thrombosis. Coronary thrombosis or heart attack occurs when a blood clot blocks one of the main blood vessels supplying the heart resulting in the heart being deprived of blood and sometimes stopping it altogether. Smoking makes blood thicker and easier to clot. Nicotine can interfere with normal and regular heart rhythms, resulting in sudden death from a heart attack without warning and is more common in people who smoke than in nonsmokers.

3. Cancer. Cancer is a disease that occurs in several parts of the body as a result of the cells multiplying suddenly and not stopping, 
sometimes the clumps of cells are destroyed and carried in the bloodstream to other parts of the body and then the same thing over and over again. Sudden cell growth can occur when cells in a part of the body are stimulated by certain substances for a long period of time. This substance is carcinogenic which means it produces cancer. In tobacco tar, there are a number of chemicals that are carcinogenic. In addition, there are also a number of cocarcinogenic chemicals that do not cause cancer on their own but react with other chemicals and stimulate the growth of cancer cells. Storage of tobacco tar mostly occurs in the lungs so lung cancer is the most common type of cancer. Tobacco tar can cause cancer if it stimulates the body for long enough, usually in the mouth and throat area.

4. Bronchitis or inflammation of the throat branches. The cough that smokers suffer is known as smoker's cough, which is an early sign of bronchitis, which occurs because the lungs are unable to release the mucus in the bronchi normally. Mucus is a sticky fluid that is contained in the fine tubes, namely the bronchial tubes that are located in the lungs. This cough occurs because the mucus traps black powder and dust from the inhaled air and prevents them from clogging the lungs. The mucus and all the waste moves through the bronchial tubes with the help of fine hairs called cilia. The cilia continue to move in waves like tentacles which carry mucus out of the lungs to the throat. Cigarette smoke can slow down the movement of cilia and after a period of time will completely destroy them and cause the smoker to cough more to expel mucus. Because the respiratory system is not working perfectly, it is easier for smokers to suffer from pneumonia, which is called bronchitis (Nururrahmah, 2014).

Smoking actually messes up the family's financial structure. However, that awareness is not enough if it is not accompanied by a strong will and intention to give up smoking addiction. So it is clear that by quitting smoking at least household finances or family finances can be managed wisely. As a result of smoking opium, smokers/staff and students do not hesitate and feel ashamed to smoke their cigarettes in the campus environment. The respondents also had mixed answers about this. They smoke inside the campus building because there is no strong prohibition from the campus leadership.

This smoking prohibition should also be balanced. This means that for those who are obedient and care about not smoking on campus, efforts are made to provide rewards, while those who violate them are given punishment clearly and proportionally. Reward and punishment are two forms of methods in motivating someone to do good and increase their performance. Reward means a gift, reward or reward, while punishment is defined as a punishment or sanction. Basically, both are needed in motivating someone, in motivating employees to improve their performance. Both are reactions from a leader towards the performance and productivity shown by his subordinates (Maharrani, 2015).

As is the case at the University of Indonesia, those who are responsible for implementing policies are the leadership and the entire academic community. Students who smoke in public places will be fined and those who receive 
scholarships will have their scholarships deducted, while individuals who report will be rewarded with a fine paid by the smoker. If the one who smokes is a lecturer or staff, their salary will automatically be deducted and given to the reporter (Maharrani 2015). If UID is really concerned about the spirit of becoming a Smoke-Free Campus, it should lead to what the University of Indonesia does.

As a campus that is labeled Islam, it is only natural for all elements and the academic community to optimize the implementation of Islamic teachings properly. In particular, the smoking culture does not have to exist in the UID environment. Smoking seems to be recognized as a culture, but it is time for the smoking culture to be a prohibition done today. In this day, information and socialization about the dangers of smoking is more widely known than in ancient times. This means that information literacy should at least provide a significant shift in the paradigm of the dangers of smoking.

Another hypothesis, is it because lecturers and employees or maybe campus policy makers are still showing the smoking culture to students. This hypothesis can be real, because based on the answers from respondents that they tried smoking because they saw other people smoking in the campus area. Therefore, lecturers and staff should be careful not to smoke in the campus area, because there are many pairs of eyes ready to imitate bad behavior (smoking) which they will try once, twice, and then become addicted.

Therefore, smoking behavior in the campus environment can be said to be a hidden curriculum. That is, the hidden curriculum, namely teaching that someone gives without knowing that others imitate it. Attitudes and habits that are carried out can easily be imitated by just looking. It is important to be a common concern that maintaining attitudes and behavior should be endeavored to maintain, because consciously or unconsciously, other people easily take lessons from us. This is what every smoker should know, he should look at the situation and conditions before smoking, so that other people do not follow a bad trail and in the hope that he will quit smoking himself.

Furthermore, smokers can also be indicated as disturbing and harming others. Because cigarette smoke emitted by smokers is also inhaled by those who are not smokers (passive smokers). Thus, both active and passive smokers get the dangers caused by smoking. Given these dangers, it becomes a common awareness to choose the right place to smoke. It is not changing viewpoints such as indifference to clean air rights for others. Although basically smokers have various arguments to smoke anywhere and anytime, the rights of others must also be respected absolutely.

The smoke exhaled when smoking can be divided into two, namely the main smoke and the side smoke. Main smoke is the part of tobacco smoke that is inhaled directly by smokers, while side smoke is tobacco smoke that is spread into the air and can be inhaled by other people who are in the same room and are known as passive smoking. Of the thousands of types of chemicals found in cigarettes, 40 of which are carcinogenic and have been identified, including: benzo (a) pyrene, cadmium, nickel, zinc, carbon monoxide, floor cleaning fluids, and nitrogen oxides, where these toxic materials are abundant. on the side smoke. Carbon monoxide is five times as much in the side fumes, three times as much 
benzo(a)pyrene, and fifty times as much ammonia in the side fumes. These materials can last several hours in the room after smoking is stopped. Therefore, cigarette smoke in the air can increase the risk of heart disease (Mulyono, 1995).

One respondent gave information that campus leaders needed to provide a smoking area (smoking area) in the campus environment. According to the researcher, it is fine if the campus leadership considers these suggestions, but seeing its effectiveness at UID, there is no need to provide a special room because the limitations of the building should also be a major consideration. If there is a room reserved for smoking, it would be better if the room is used as a lecture room.

Thus, it is necessary for smokers to find a place that fits him. Do not choose to smoke in the campus building, because this is very disturbing for every student or lecturer who is doing activities on campus. Until now, students and lecturers can still be found easily and feel used to smoking in the building. They can actually stop smoking during lectures, and they can also find a large area, such as an off-campus environment, to smoke.

Returning to individual awareness, this shows that smoking can be controlled at random. This awareness can be presented by self-control or through a well-developed and implemented rule. Self-awareness can arise if there is an attitude of respecting the rights of others, respecting established regulations, and maintaining a clean environment. However, the best consciousness is that which is born out of a sincere attitude of the heart, not because of any compulsion. And obey the rules of prohibiting smoking both when people are seen, and when no one is watching.
The Governor of Jakarta issued Governor Regulation No. 75 of 2005 concerning No Smoking Areas. The Governor Regulation stipulates places that must be made smoke-free areas. This includes public places, work, schools, health service facilities, children's activity arenas, places of worship, and public transportation. In addition, it also regulates the obligations that must be carried out by the leaders and/or people in charge of these places. From the Governor's declaration, he explicitly emphasized that school or university areas should be made smoke-free areas. In this case, UID who are domiciled in the Jakarta Province should also take part in implementing the regulation.

And the most phenomenal is that the majority of respondents or more than $60 \%$ of respondents agreed with the prohibition of smoking in the UID campus environment. This matter can be a note for campus leaders to immediately form a team and establish a smoking prohibition on campus. Although this is limited to the UID environment, researchers believe that there are many benefits if the smoking prohibition policy could be triggered. Beneficial such as a clean and green environment (go green), and it is also hoped that it can emphasize non-smokers not to smoke and also minimize the number of smokers in the campus environment.

The application of $100 \%$ smoke-free areas is essential to save lives. The prohibition of smoking in smoking-free areas will have a health impact on both smokers and non-smokers. This prohibition will reduce nonsmokers' exposure to environmental tobacco smoke and reduce cigarette consumption among smokers (DepKes, 2004). The regulations that will be promulgated by the UID leadership will be able to provide great hope for all parties, both smokers and 
non-smokers, to be able to maintain their health.

In line with that, the Government through the Minister of Health and the Minister of Home Affairs issued Joint Regulations Number 188 of 2011 and Number 7 of 2011 concerning Guidelines for the Implementation of Non-Smoking Areas which were compiled by two ministries, this is because these two ministries are very instrumental and responsible for this problem. . The Minister of Health in the joint regulation on guidelines on smoking free areas has a role related to human health because cigarette smoke can cause several dangerous diseases. Meanwhile, the Minister of Home Affairs plays a role in his relationship with local governments in drafting smoking-free area regulations and also in determining places that are smoke-free areas (Shirley, 2016).

Thus, there is no other reason that almost all respondents representing the UID population agreed with the smoking prohibition regulation. University leaders should plan and consider as early as possible and determine what is best for the campus environment. The regulation is very reminiscent of all parties, and on the other hand, the regulation will be a characteristic of the UID campus which supports the upholding of Islamic preaching. Especially, Islamic da'wah which advocates implementing good (ma'ruf) and preventing others from shunning bad (munkar) deeds. Smoking in this case is a bad act, because it is categorized as a makruh behavior, some even say it is haram.

For this reason, University leaders need to provide education and socialization about the dangers of smoking. And the idea that was initiated was also supported by students and respondents, it was proven that more than $60 \%$ of the respondents stated that they were ready to support and participate if educational and socialization activities were carried out by university leaders. Hopefully this hope can be in line with the Rector's program, and can be implemented in a real way.

As a consideration for University leaders, they should schedule the campus budget in implementing educational programs and socializing material about the dangers of smoking. "Material about disclosure and regulation of tobacco product content. Apart from tar and nicotine, there are many additives, both natural and synthetic, in tobacco products. Some of them are safe for consumption, but the potential negative impact on health when inhaled is unknown (Achadi, 2008)." These programs will be able to provide enlightenment for all parties who hear, see, and know the information conveyed through the program. If this program continues to be rolled out, it becomes inevitable that the smoking habit will decrease, or other smokers will no longer exist, and more importantly those who smoke in the UID campus environment will feel embarrassed and reluctant.

If the smoking prohibition policy can be rolled out, it is inevitable that the campus environment will be beautiful, peaceful and free of cigarette smoke pollution. Furthermore, everyone who is part of UID realizes that smoking is the gateway to the entry of addiction to a higher level, namely using drugs. Unfortunately, out of all the respondents interviewed, only $17 \%$ believed smoking was a bad door. This means that education and socialization efforts need to be implemented in the UID environment.

It is common knowledge that smoking is the first step for every addict to use drugs. Although, this matter is not understood by all parties or smokers themselves, because there are also smokers who do not use drugs. However, 
it can be noticed that the dominant drug users are smokers. Elementary, junior high and high school students start their naughty interactions by always making friends with cigarettes. They gathered together to share cigarettes, one cigarette was smoked together, joked, finally they were addicted. And always repeat and repeat the smoking habit.

Finally, an offer was rolled out from the bad guys by offering rolled cigarettes containing marijuana or other sedatives. They feel calm or fly, and the worst they are will tend to try other types of drugs. of course if you have this, the level of addiction and even "madness" cannot be avoided if not rehabilitated. On the other hand, the costs incurred to buy drugs or other illicit goods are not cheap, they even buy quite an expensive price tag because they are addicted. The expenditure of funds becomes worse if they enter the rehabilitation stage later. Those who end up being rehabilitated are certainly expected to be good, but there are not a few deaths/loss of life due to drug addiction.

Therefore, the University leaders can hold various socialization activities, one of which is by scheduling a "stop smoking" campaign continuously and evenly across all faculties. Based on interviews with respondents that they are willing to take part in the campaign activities. This voice must be heard by all policy makers so that this idea does not remain in a pile of writings that have lost its usefulness. To maximize this big agenda, campus leaders should also form an evaluation team or monitors and supervisors who pay attention to the implementation of policies issued by the rector.

Involving all parties to participate in smoking prevention activities should be appreciated. If necessary, the University leaders will hold a selection and choose an Anti-Smoking Ambassador in the UID environment. This sounds trivial, but the words echoed by the researchers are quite significant. Given the conditions in the UID environment that smoke seems free and in any place. And the Anti-Smoking Ambassador must always be supported both in terms of work programs and program funding. Because, in the UID environment being an ambassador will face no small challenges, such as exclusion from smoker friends, being considered pretentious, and many more. So Dutta's pride is at stake on the program.

Finally, of all respondents interviewed, $72 \%$ said they had a strong desire to quit smoking. Apart from being self-motivated, this desire should also be helped from outside oneself. From outside the smoker, for example with a friend who always reminds him about the dangers of smoking and a campus that implements a smoking prohibition. Given the data and information found in UID, there is still very low desire of the UID campus community with the proposed prohibition on smoking to be enforced. Researchers see this matter occurs because there has been no concrete effort from the campus leadership to educate and socialize the campus community to know the dangers of smoking from many aspects.

It can be used as a comparison of the model developed by the RBAR Program in Yogyakarta. In every socialization it is always emphasized that this program is not a program that prohibits people from smoking or asks smokers to quit smoking. The RBAR program is just a program that urges smokers to care more about the health of their loved ones, by not smoking in the house. This is done so that there is no rejection among smokers. When members of the community agree to carry out this program, a declaration is made in which 3 agreements are always listed, namely: 1) No smoking in the house, 2) No smoking at community meetings, and 3 ) 
Not providing an ashtray at home and at community meetings (Ramadan, 2017).

RBAR stands for Rumah Bebas Asap Rokok (Smoke-Free House) which is a program initiated by Quit Tobacco Indonesian (QTI) in 2010 in 4 villages in Yogyakarta. This movement is an implementation of a no-smoking policy at the household level that has succeeded in reducing the number of husbands and other family members who smoke from $54 \%$ to $37.6 \%$ and smoke in the home from $87 \%$ to $37.1 \%$. This program is a smoking activity outside the home and is the most acceptable tobacco control activity. The RBAR program should have been a supporter of the KTR policy (Padmawati in Ramadhan, 2017).

RBAR programs can be a consideration for UID leaders to hold socialization in the form of a declaration, such as 1) No smoking in the campus building, 2) No smoking in the campus environment when gathering together in student activities, and 3) Not providing an ashtray in the lecturer room . After the declaration with the awareness to stop smoking was strengthened again by the way the campus leadership formed a regulation that binds all parties to implement mutually agreed points of the declaration. Regarding the contents of the declaration, it can be adjusted with considerations, work programs, financing, and evaluations in line with the spirit of the UID vision.

Thus, regarding the smoking prohibition model in the UID environment still needs to be applied, therefore it is necessary to pay attention to many things in the preparation so that the regulations that are formed later can be applied in the UID environment. University leaders must seriously support the existence of this smoking prohibition regulation. The most important factor is leadership support. The process of implementing a policy, the role and support of the leadership are very decisive. Leaders not only make policies, but also provide examples in implementing these policies. The behavior of a leader greatly influences the effectiveness of implementing a policy. Policy implementation should be a simple matter if the leadership role is played well. The assertiveness of a leader is needed for the implementation of any policies made. The regulations made will be useless if they do not have the full support of the leadership as local government (Popa, 2016).

And this research should not only end as a formality of research, but there are concrete efforts to implement regulations prohibiting smoking in the UID environment. According to researchers this is very crucial at UID. Because, considering the suggestions of many respondents and seeing that most other campuses have implemented a smoking prohibition policy. And now it is the turn of the Jakarta Islamic University to make and implement the Smoking Prohibition Regulation.

\section{Conclusion}

From the results of the data findings and the discussion that has been narrated above, this research can be concluded as follows; First, The response to the establishment of a smoking prohibition policy in the UID environment is still low. Does not reach more than more than $70 \%$ of the respondents' answers. This indicates the need for comprehensive and continuous education and socialization about the dangers of smoking in the UID environment. So that in the future, the policy to prohibition smoking regulations can be enforced. Second, A smoking prohibition policy model that can be pursued by university leaders is to hold various activities that support the go green program. As; stop smoking campaigns, hold seminars or workshops, and add symbols that prohibit smoking in the UID 
environment. With the hope, smokers who read it can realize that their behavior is not good, and those who are not smokers can stay away and avoid cigarette consumption.

Based on the research that has been done, recommendations that can be followed up are as follows;

a. Allocating funds for the socialization program for regulations and smoking prohibition programs in the UID environment.

b. Organizing education and socialization about the dangers of smoking, such as socialization on the prohibition of smoking that can be delivered at the admission of new students or in seminars/workshops/student activity week which gather many students / lecturers.

c. Hold a Declaration of No Smoking in the UID Campus Environment.

d. Organizing competitions and awarding Anti-Smoking Ambassadors in the UID Campus Environment.

e. Campus leaders and all lecturers and employees exemplify good behavior by not smoking in public or in buildings.

f. Issued regulations/policies on smoking prohibition with legal force. Policies that are not only appeal but binding for all parties, there are rewards and punishments for the regulation.

g. Providing facilities and infrastructure such as distributing newsletters, leaflets, booklets, and installing prohibitionners, billboards, and warning against smoking both inside and outside the campus building.

h. Involving BEM and UKM to jointly install facilities and infrastructure with the theme of keeping the environment clean and free of cigarette smoke pollution.

i. University leaders form a team of observers who are responsible for taking notes and then reporting to the Rector for anyone who smokes in the campus environment.

\section{References}

Achadi, Anhari. "Regulasi Pengendalian Masalah Rokok di Indonesia”, KESMAS, Jurnal Kesehatan Masyarakat Nasional, Vol. 2, No. 4, 2008.

Aditama, Tjandra Yoga. Rokok Masalah Dunia, Jurnal Kedokteran dan Farmasi, No.9 Tahun XXI, PT. Grafiti Medika Pers, Jakarta, 1995.

Atkinson. Pengantar Psikologi. Jakarta, 1999.

Marsito, dkk, "Kontribusi Fungsi Keluarga terhadap Perilaku Remaja Merokok di SMA/SMK Kecamatan Gombong, Kebumen Jawa Tengah”, Jurnal Ilmiah Kesehatan Keperawatan, Vol.5, No.3, 2009: h.169

Departemen Kesehatan RI. The Tobacco Source Book: Data to Support A National Tobacco Control Strategy. Jakarta: Departemen Kesehatan RI, 2004.

Maharrani, Elsa, dkk. "Studi Implementasi Kebijakan Larangan Merokok Di Universitas Andalas Tahun 2012", Jurnal Kesehatan Masyarakat Andalas, Vol.9, No.1, 2015.

Mulyono, Djoko. Merokok dan Penyakit Kardiovaskuler, Jurnal Kedokteran dan Farmasi, No.9. Tahun XXI, PT. Grafiti Medika Pers, Jakarta, 1995.

Nururrahmah. "Pengaruh Rokok terhadap Kesehatan dan Pembentukan Karakter Manusia”, Prosiding Seminar Nasional, Vol. o1, No.1, 2014. 
Peraturan Gubernur DKI Jakarta No. 75 Tahun 2005

Popa, Sudarmi, dkk. "Evaluasi Pelaksanaan Peraturan Kawasan Larangan Merokok Pada Perilaku Merokok Pegawai Pemerintah di Boalemo", Gorontalo Berita Kedokteran Masyarakat, Vol.32, No.3, 2016.

Prabandari, dkk. "Kawasan Tanpa Rokok sebagai Alternatif Pengendalian Tembakau Studi Efektivitas Penerapan Kebijakan Kampus Bebas Rokok terhadap Perilaku dan Status Merokok Mahasiswa di Fakultas Kedokteran UGM, Yogyakarta”, Jurnal Manajemen Pelayanan Kesehatan, Vol.12, No.4, 2009: h.218

Priyatin, dkk "Pengaruh Fungsi Keluarga terhadap Perilaku Merokok Remaja di Desa Waluyorejo Kecamatan Puring Kabupaten Kebumen, Jurnal Ilmiah Kesehatan Keperawatan, Vol.5, No.1, 2009.

Ramadhan, Kadar. "Hubungan Larangan Merokok di Rumah dengan Keberhasilan Berhenti Merokok",
Jurnal Profesi Medika, Vol.11, No1, 2017.

Salmawati, dkk. "Hubungan Perilaku dengan Kebijakan dan Kebiasaan Merokok Siswa Kelas VII dan VIII di SMP Negeri 5 Palu tahun 2015". Jurnal Preventif, Vol.7, No.2, 2016: h.18

Shirley, Kwe Fei Lie, dkk. "Kebijakan Tentang Pedoman Kawasan Tanpa Rokok Dikaitkan dengan Asas Manfaat “, SOEPRA Jurnal Hukum Kesehatan, Vol. 2, No.1, 2016.

Sugiyono. Metode Penelitian Pendidikan: Pendekatan Kuantitatif, Kualitatif danRnD. Bandung: Alfabeta, 2007.

Trianto. Model Pembelajaran Terpadu Dalam Teori Dan Praktek. Surabaya: Pustaka Ilmu, 2007.

Umar, dkk, "Perilaku Merokok dan Lingkungan Pemukiman Pasien Rawat Jalan Penyakit Jantung Koroner di Makassar", Jurnal Media Gizi Masyarakat Indonesia, Vol.1, No.1, Agustus 2011.

Undang-Undang Kesehatan No 36 tahun 2009 pasal 115 